\title{
Fibronectin glycation increases IGF-I induced proliferation of human aortic smooth muscle cells
}

\author{
Maria Lúcia Corrêa-Giannella ${ }^{1}$, Maria Regina Andrade de Azevedo², Derek LeRoith ${ }^{3}$ and Daniel Giannella-Neto ${ }^{4^{*}}$
}

\begin{abstract}
The advanced glycation end products, namely AGEs, contribute to long-termed complications of diabetes mellitus, including macroangiopathy, where smooth muscle cells (SMC) proliferation stimulated by platelet-derived growth factor (PDGF) isoforms and insulin-like growth factor-I (IGF-I) plays an important role. The objective of the present study was to investigate the effect of an AGE-modified extracellular matrix protein on IGF-I induced SMC proliferation and on the IGF-I-IGF binding protein 4 (IGFBP-4) axis under basal conditions and after stimulation with PDGF-BB. IGF-I resulted in significantly higher thymidine incorporation in SMC seeded on AGE-modified fibronectin (AGE-FN) in comparison to cells seeded on fibronectin (FN). This augmented proliferation could not be accounted for by increased expression of IGF-IR, by decreased secretion of IGFBP-4, a binding protein that inhibits IGF-I mitogenic effects or by increased IGF-IR autophosphorylation. PDGF-BB did not modulate IGF-IR and IGFBP-4 mRNA expression in any of the substrata, however, this growth factor elicited opposite effects on the IGFBP-4 content in the conditioned media, increasing it in cells plated on FN and diminishing it in cells plated on AGE-FN. These findings suggest that one mechanism by which AGE-modified proteins is involved in the pathogenesis of diabetesassociated atherosclerosis might be by increasing SMC susceptibility to IGF-I mitogenic effects.
\end{abstract}

Keywords: Diabetes mellitus, Advanced glycation end products (AGE), Smooth muscle cells, PDGF, IGF-I, IGFBP-4

\section{Background}

Both type I and type II diabetes are powerful and independent risk factors for coronary artery disease, stroke, and peripheral arterial disease [1,2]. Prolonged exposure to hyperglycemia is recognized as the primary casual factor in the pathogenesis of diabetic complications [3,4]. Hyperglycemia induces a large number of alterations in vascular tissue that potentially promote accelerated atherosclerosis. Glycation of proteins is an important biochemical mechanism by which glucose mediates tissue damage, leading to the generation of advanced glycation endproducts (AGEs) and modifying the structure and function of several proteins, such as those which comprise extracellular matrixes [5]. It has been demonstrated that AGE formation alters some functional properties of collagen [6], vitronectin [7], laminin [8], and fibronectin (FN) [9], affecting their self-assembly and their binding to each other. AGEs can also induce

\footnotetext{
* Correspondence: dgiannella@lim07.fm.usp.br

${ }^{4}$ Laboratory for Clinical and Experimental Gastroenterology (LIM-07). Hospital das Clínicas da Faculdade de Medicina da Universidade de São Paulo, Av. Dr. Arnaldo, 455, Sala \#4387, São Paulo, Brazil

Full list of author information is available at the end of the article
}

synthesis and secretion of cytokines and growth factors after binding to AGE receptors (RAGE) in different cell types [7]. Monocytes exposed to AGE-modified matrix release tumor necrosis factor- $\alpha$ (TNF- $\alpha)$ [10], platelet-derived growth factor (PDGF) [11] and insulin-like growth factor-I (IGF-I) [12]. In vascular smooth muscle cells (SMC) AGE-RAGE interaction has been shown to activate cell signalling pathways linked to expression of inflammatory and prothrombotic genes, such as ERK1/ERK2 kinases and NF-kB [13].

The SMC, which constitute the medial layer of arteries, are normally in a differentiated contractile phenotype, but during the development of atherosclerotic lesions, a subpopulation of SMC is converted to a synthetic phenotype that is able to migrate and proliferate. Extracellular matrix proteins actively participate in this process, affecting SMC phenotype and modulating the cellular response to growth-regulatory molecules [14]. FN, which is found in increased amounts in early atherosclerotic plaques $[15,16]$, can interact with cell surface receptors and promote the conversion of SMC to the synthetic state [17] and growth factors such as PDGF and IGF-I will act, respectively, as competence and 
progression factors for cell replication [18], exerting synergistic effects on SMC proliferation [19]. IGF-I is synthesized by vascular SMC where it is regulated by several factors, such as PDGF [20-22]. The final biological activity of IGF-I is determined by the number and affinity of its receptors (IGF-IR) as well as by its binding proteins (IGFBP) [23]. IGFBP-4, whose secretion is also modulated by PDGF [22,24], is one of the predominant IGFBPs produced by vascular SMC in culture, where it has an inhibitory effect on IGF-I- induced DNA synthesis [25].

The present study examined the effect of AGE-modified FN on IGF-I induced SMC proliferation as well as on the expression of IGF-IR and IGFBP-4 and their modulation by PDGF-BB, in order to investigate pathways that could be involved in diabetic macroangiopathy.

\section{Materials and methods}

This study was approved by the Institution's Ethic Committee (Comitê de Ética em Pesquisa do Hospital das Clínicas da Faculdade de Medicina da Universidade de São Paulo).

\section{Materials}

Fibronectin and other routine reagents were obtained from Sigma Chemical Co. (St. Louis, MO), IGF-I and Des (1-3) IGF-I were supplied by GroPep (Adelaide, South Australia), PDGF-BB and all materials for cell culture were obtained from Life Technologies (Gaithersburg, MD). Iodinated $\left[{ }^{125} \mathrm{I}\right]$ des (1-3) IGF-I, $\left[{ }^{125} \mathrm{I}\right]$ labelled Protein A $(100 \mathrm{mCi} / \mathrm{mL})$ and $\mathrm{ECL}$ detection kit were purchased from Amersham (Arlington Heights, IL). Antibody 1.2, a monoclonal antibody to the C-terminus of the IGF-I receptor, was a kind gift from Dr. Kenneth Siddle (Cambridge, UK). Anti-IGFBP-4 antibody was obtained from Upstate Biotechnology, Inc. (Lake Placid, NY). Antiphosphotyrosine antibody ( $\mathrm{RC} 20 \mathrm{H})$ conjugated to horseradish peroxidase was purchased from BD Transduction Laboratories (Lexington, KY).

\section{Preparation of AGE-modified FN}

FN $(2.5 \mathrm{mg})$ was incubated in phosphate-buffered saline (PBS) (pH 7.4) with $500 \mathrm{mM}$ D-glucose at $37^{\circ} \mathrm{C}$ in the presence of protease inhibitors (1.5 $\mathrm{mM}$ phenylmethylsulfonyl fluoride [PMSF], $0.5 \mathrm{mM}$ EDTA) and antibiotics (100 U/mL penicillin, $100 \mu \mathrm{g} / \mathrm{mL}$ streptomycin) for 6 weeks. Control FN was incubated under the same conditions without glucose. Unreacted sugar was removed by dialysis against PBS. Characteristic fluorescence of the AGE compound 2-(2-furoyl)-4(5)-(2-furanyl)-1 H-imidazole (FFI) was observed at $440 \mathrm{~nm}$ after excitation at $375 \mathrm{~nm}$ [26]. FN structural modification secondary to advanced glycation was established by assessing bityrosine formation $(400 \mathrm{~nm}$ upon excitation at $325 \mathrm{~nm}$ ) and tryptophan quenching (334 $\mathrm{nm}$ upon excitation at $275 \mathrm{~nm}$ ) [27] (Figure 1). Control and AGE-modified FN were evaluated on sodium dodecyl sulfate-polyacrylamide gel electrophoresis (SDSPAGE) [28] using a 5\% stacking gel and a 7.5\% separating gel and they exhibited indistinguishable electrophoretic patterns, without any sign of degradation (data not shown). Control and AGE-FN were plated at $4 \mu \mathrm{g} / \mathrm{cm}^{2}$ either onto 12-well tissue culture plates or onto $75 \mathrm{~cm}^{2}$ culture flasks for $1 \mathrm{~h}$ at room temperature (RT). The plates were gently rinsed three times with $\mathrm{PBS}$ before SMCs were allowed to adhere.

\section{Evaluation of SMC proliferation}

An immortalized SMC line (AALTR-16) was kindly provided by Dr. J.K. McDougall (Fred Hutchinson Cancer Research Center, Seattle, WA): human aortic SMCs were infected with a retro viral vector containing the E6/E7 open reading frame of human papilloma virus type 16 . The E6 protein binds and promotes the degradation of the wild-type p53 protein and the E7 protein forms an inactivating complex with the product of the retinoblastoma tumorsuppressor gene. These cells did not show any tumorigenic activity in irradiated nude mice [29] and their characterization by immunocytochemical studies and electronic microscopy demonstrated, respectively, expression of alpha -smooth muscle actin and a synthetic phenotype, featured by a prominent endoplasmic reticulum. Lack of oncogenic transformation was evaluated by serum dependent assay (data not shown). The cells were maintained in medium supplemented with 10\% FCS, $1 \mathrm{mM}$ l-glutamine, $100 \mathrm{U} / \mathrm{mL}$ penicillin and $100 \mu \mathrm{g} / \mathrm{mL}$ streptomycin at $37^{\circ} \mathrm{C}$ in a humidified atmosphere of $95 \%$ air - $5 \% \mathrm{CO}_{2}$, with medium changes three times a week. Every five days, the cells were harvested with a solution of $0.25 \%$ trypsin. To study the effect of AGE-FN on SMC proliferation, cells were seeded at $2 \times 10^{4}$ cells $/ \mathrm{cm}^{2}$ into 96 -well plates coated with either FN or AGE-FN and were cultured in medium supplemented with 10\% FCS until sub-confluence. After incubation with serum-free medium for 24-h, cells were incubated for $24 \mathrm{~h}$ in serum-free medium (baseline) or in medium containing IGF-I (the concentration of $100 \mathrm{ng} / \mathrm{mL}$ was used because a dose-response curve did not show a significant effect of 10,25 and $50 \mathrm{ng} / \mathrm{mL}$ of IGF-I on SMC proliferation [data not shown]). After medium aspiration, fresh medium containing $2 \mathrm{mCi} / \mathrm{mL}$ of [methyl-3 $\mathrm{H}$ ] thymidine (Amersham) was added for additional $4 \mathrm{~h}$. The cells were rinsed twice with ice-cold PBS, twice with ice-cold 5\% trichloroacetic acid, and twice with ice-cold 95\% ethanol. The cells were lysed in $0.3 \mathrm{~mL}$ of $1 \mathrm{~N} \mathrm{NaOH}$, neutralized with $0.3 \mathrm{~mL}$ of $1 \mathrm{~N} \mathrm{HCI}$, and counted in a liquid scintillation counter. The results are expressed as the mean \pm SEM of four independent experiments performed in duplicates.

\section{IGF-I binding assay}

SMC were seeded into 12-well plates coated with FN or AGE-FN and were grown in medium supplemented with 

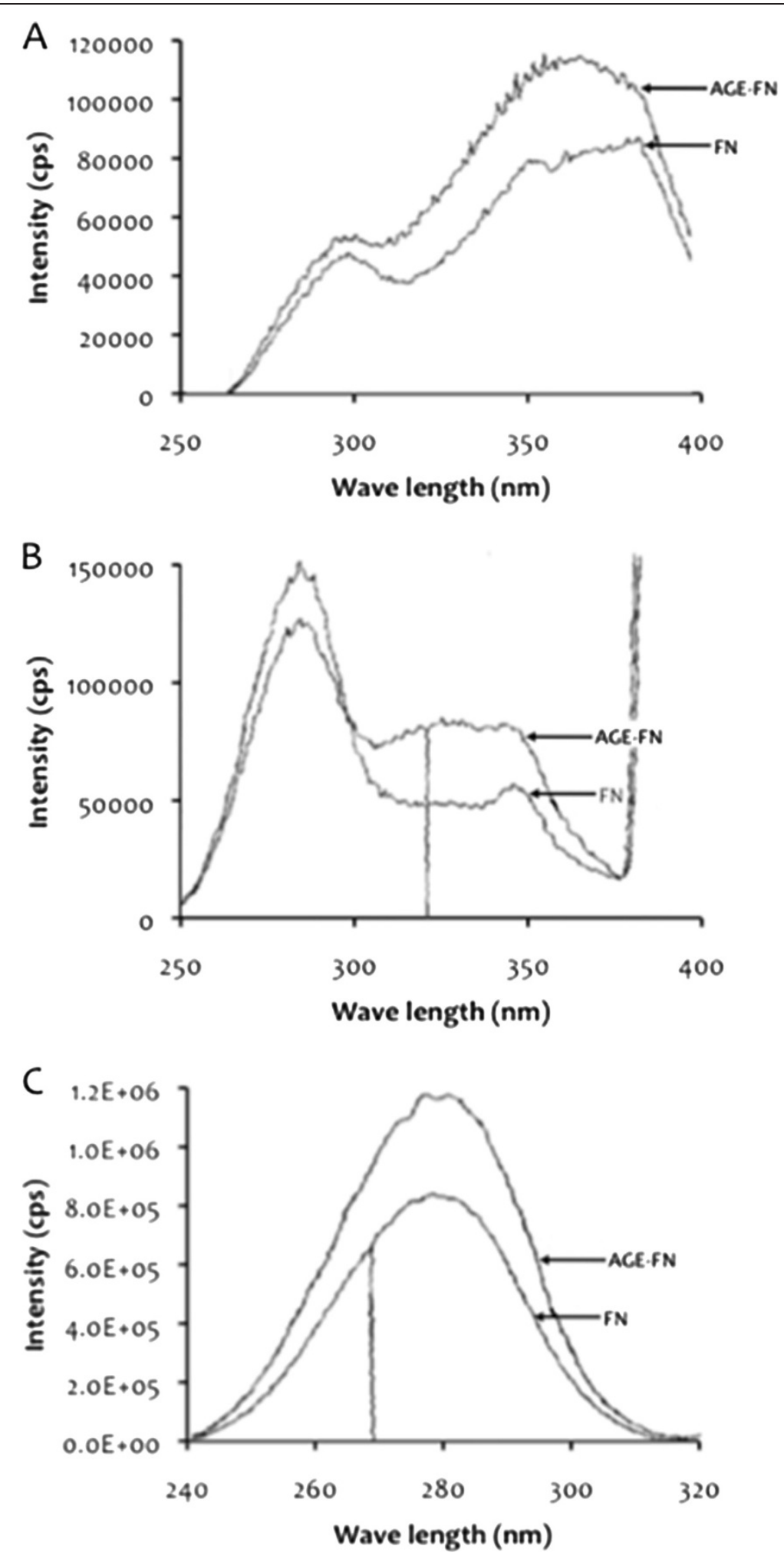

Figure 1 Characterization of AGE-modified FN (AGE-FN). Fluorescence of the AGE compound FFI observed at $440 \mathrm{~nm}$ after excitation at $375 \mathrm{~nm}$ (Panel A). Fibronectin (FN) structural modification secondary to advanced glycation was established by assessing bityrosine formation (400 nm upon excitation at 325 nm) (Panel B) and tryptophan quenching (334 nm upon excitation at $275 \mathrm{~nm}$ ) (Panel C). 
10\% FCS until sub-confluence. After incubation with serum-free medium for 24-h, the cells were washed with $1 \mathrm{~mL}$ of ligand binding buffer and incubated in $0.5 \mathrm{~mL}$ of binding buffer containing 25,000 cpm of radiolabeled material $\left({ }^{125}\right.$ Des (1-3) IGF-I) and unlabeled competitor (Des (1-3) IGF-I) in the following final concentrations: $0,0.5,1,2,4,8,16,32$ and $100 \mathrm{ng} / \mathrm{mL}$ as previously described [30]. Total binding was designated as the quantity of labeled ligand bound under these conditions. Nonspecific binding was defined as the radioligand bound in the presence of a 100-fold molar excess of unlabeled ligand. Specific binding was calculated as the difference between total and nonspecific binding. ${ }^{125}$ Des (1-3) IGF-I binding kinetics were calculated using a LIGAND computer program [31]. The results are expressed as means \pm SEM of three independent experiments performed in duplicates.

\section{IGF-IR protein content and autophosphorylation}

IGF-IR protein levels were determined by immunoblotting membranes containing cell lysates of SMC seeded into 100-mm plates coated with FN or AGE-FN, grown in medium supplemented with $10 \%$ FCS until subconfluence and synchronized by serum starvation for 24-h with antibody 1.2, a monoclonal antibody to the C-terminus of the IGF-IR, as previously described [32]. Three independent experiments were performed. IGF-IR autophosphorylation was analyzed by immunoblotting in cell lysates (75 mg) with an antiphosphotyrosine antibody, as previously described [32]; SMC seed into $100-\mathrm{mm}$ plates coated with FN or AGE-FN were grown in medium supplemented with 10\% FCS until sub-confluence and after synchronization for 24-h, cells were incubated either with or without IGF-I $(100 \mathrm{ng} / \mathrm{mL})$ for $1 \mathrm{~min}$ at $37^{\circ} \mathrm{C}$. Three independent experiments were performed.

\section{IGFBP-4 detection}

To study the effect of AGE-modified FN on IGFBP-4 secretion, cells were plated at $3 \times 10^{4}$ cells $/ \mathrm{cm}^{2}$ into $75 \mathrm{~cm}^{2}$ culture flasks coated with FN or AGE-FN, and were grown in medium supplemented with 10\% FCS until sub-confluence. After being rinsed twice, they were incubated with serum-free medium supplemented with $1 \mathrm{mM}$ l-glutamine and antibiotics for 24-h. The medium was then replaced with or without addition of PDGF-BB $(10 \mathrm{ng} / \mathrm{mL})$ for $24-\mathrm{h}$. The conditioned medium was collected and concentrated by ultrafiltration in $3 \mathrm{kDa} \mathrm{MW}$ cut-off Centripep columns (Amicon Inc., Beverly, MA) and protein was determined by the method described by Bradford [33]. Identification of IGFBP-4 was performed according to the anti-IGFBP-4 antibody manufacturer's Western Blot (WB) protocol (United Biotech, Inc. Mountain View, CA). Briefly, after gel electrophoresis and transference of proteins, the nitrocellulose membrane was washed twice with water and blocked with phosphate buffered saline (PBS) with 3\% non-fat dry milk for $20 \mathrm{~min}$ at RT. The membrane was then incubated with a 1:2.000 dilution of antibody anti-human IGFBP-4 (rabbit, polyclonal) in PBS $1 \%$ non-fat dry milk at $4^{\circ} \mathrm{C}$ overnight. This was followed by two washes with water and incubation for $2 \mathrm{~h}$ at RT with anti-rabbit immunoglobulin G (peroxidase-linked, Amersham) in PBS $1 \%$ non-fat dry milk. The membrane was washed twice with water, once with PBS 0.05\% Tween-20 and finally four times with water. A chemiluminescent peroxidase substrate (ECL) was applied for $1 \mathrm{~min}$ and the membrane was exposed briefly to autoradiographic film. The densities of the bands were determined by scanning densitometry. Three independent experiments were performed.

\section{Evaluation of IGF-IR and IGFBP-4 mRNA abundance}

To study the effect of AGE-modified FN on IGF-IR and IGFBP-4 mRNA content, total RNA from cells from the previous experiment was prepared using TRIzol ${ }^{\circledR}$ reagent (Invitrogen, Carlsbad, CA) accordingly to standard protocols provided by the manufacturer. RNase protection assay was performed as previously described [34] using the following probes: (I) IGF-IR probe, which is a $379 \mathrm{bp}$ fragment of human IGF-IR cDNA cloned into a pGEM3 vetor [35], (II) IGFBP-4 probe, which is a 505bp fragment of human IGFBP-4 cDNA cloned into a pBSK + vector [36] and (III) 18S RNA riboprobe, which served as an internal control. Three independent experiments were performed.

\section{Statistical analysis}

Data were analyzed by non-parametric tests. MannWhitney test was employed for two unpaired groups and and Kruskal-Wallis test when three or more groups were analyzed. Statistical significance was set to $p<0.05$. All statistical analyses were performed by JMP Version 5.01 (SAS Institute Inc. Cary, NC, USA).

\section{Results}

\section{SMC proliferation}

As shown in Figure 2, IGF-I elicited an increment significantly higher $(P<0.05)$ in thymidine incorporation in SMC grown on AGE-FN than in cells grown on FN demonstrating the stimulatory effect of AGE on SMC proliferation in the presence of IGF-I. No differences in thymidine incorporation were observed between SMC coated in FN and AGE-FN in the absence of IGF-I.

\section{IGF-I binding and IGF-IR autophosphorylation}

In order to investigate if AGE-FN promotes increased SMC proliferation by augmenting IGF-IR number and/ 


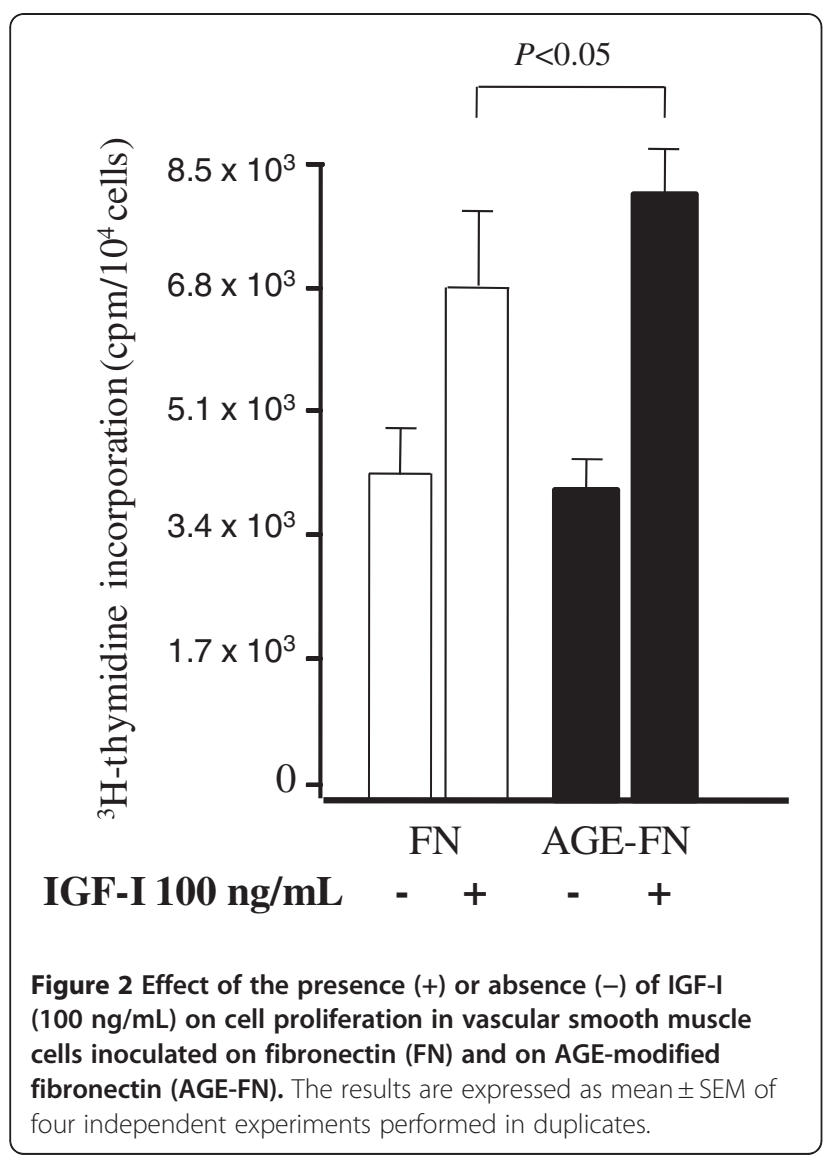

or affinity, an IGF-I binding assay was performed with Des(1-3) IGF-I, a truncated form of IGF-I (lacking the N-terminal tripeptide Gly-Pro-Glu) that has much reduced IGFBP affinity compared with natural IGF-I [37]. Thus the use of this analog avoids falsely elevated IGF-IR binding sites, which may occur with any binding of IGF-I radioligand to IGFBPs. IGF-binding curves fitted to one binding site (Figure 3 ). The receptor numbers per cell were not different between SMC plated on FN and on AGE-FN $\left(1.33 \times 10^{4}\right.$ in both conditions), neither were the relative affinities for IGF-IR (Kd of $6.64 \times 10^{-11}$ and $6.31 \times 10^{-11}$, respectively) $(P>0.05)$. Also, the evaluation of IGF-IR by Western blot did not show any significant difference between the abundance of this protein on SMC grown on FN and AGE-FN $(P>0.05)$ (Figure 4). Since changes in IGF-IR number and affinity could not explain increased cell proliferation stimulated by IGF-I in presence of AGE-FN, autophosphorylation of the IGF-IR was examined by Western blot with an antiphosphotyrosine antibody. IGF-I stimulated autophosphorylation of SMC seeded on both FN and AGE-FN did not consistently differ between the two experimental conditions $(P>0.05)$ (Figure 5).

\section{IGFBP-4 content}

To additionally investigate if a decrease in IGFBP-4, a binding protein that inhibits IGF-I mitogenic effects, was involved in the increased SMC proliferation determined by AGE-FN, a Western blotting employing an antibody antihuman IGFBP-4 was performed. As shown in Figure 6, after $24 \mathrm{~h}$ of incubation in serum-free media, the content of IGFBP-4 in the conditioned media of SMC grown on AGE-FN was similar to the observed in the conditioned media of cells seeded on FN $(P>0.05)$, however, treatment with $10 \mathrm{ng} / \mathrm{mL}$ of PDGF-BB for $24 \mathrm{~h}$ evoked opposite effects on the IGFBP-4 content, augmenting (range from $40-60 \%)$ this binding protein in the conditioned media from SMC grown on FN (as observed in cells maintained in plastic substratum [data not shown] and as described in previous studies $[22,24]$ ) and decreasing (range from 28$46 \%)$ it in the conditioned media of SMC cultivated in AGE-FN $(P<0.05)$. This result suggests that the interaction of SMC with AGE-FN modifies the dynamic of IGFBP-4 secretion induced by PDGF-BB, resulting in elevation of local free IGF-I, which may contribute to SMC proliferation.
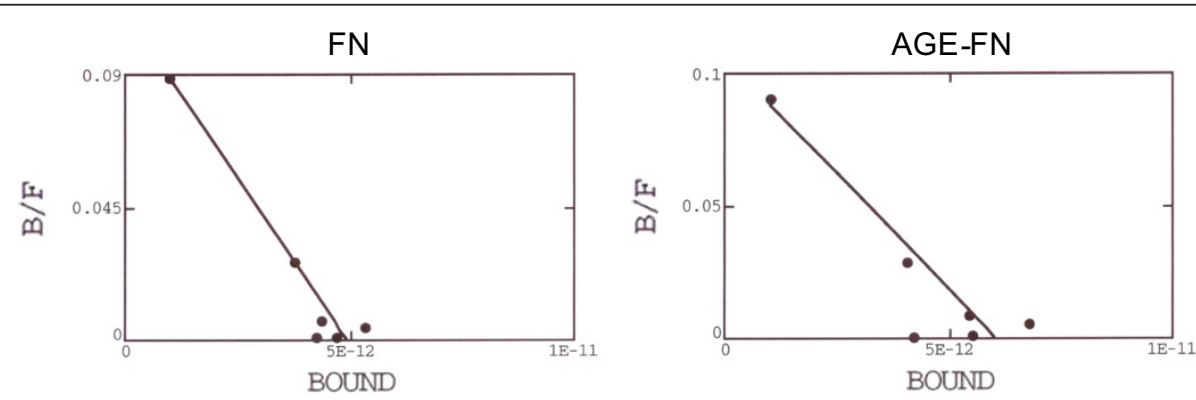

Figure 3 Scatchard plots of Des (1-3)IGF-I binding sites in vascular smooth muscle cells inoculated on fibronectin (FN) or AGEmodified FN (AGE-FN). The abscissa shows bound ${ }^{125}$ Des (1-3)IGF-I; the ordinate indicates the ratio of bound (B) Des (1-3)IGF-I to free (F) Des $(1-3)$ IGF-I. A plot representative of three independent experiments is shown. 


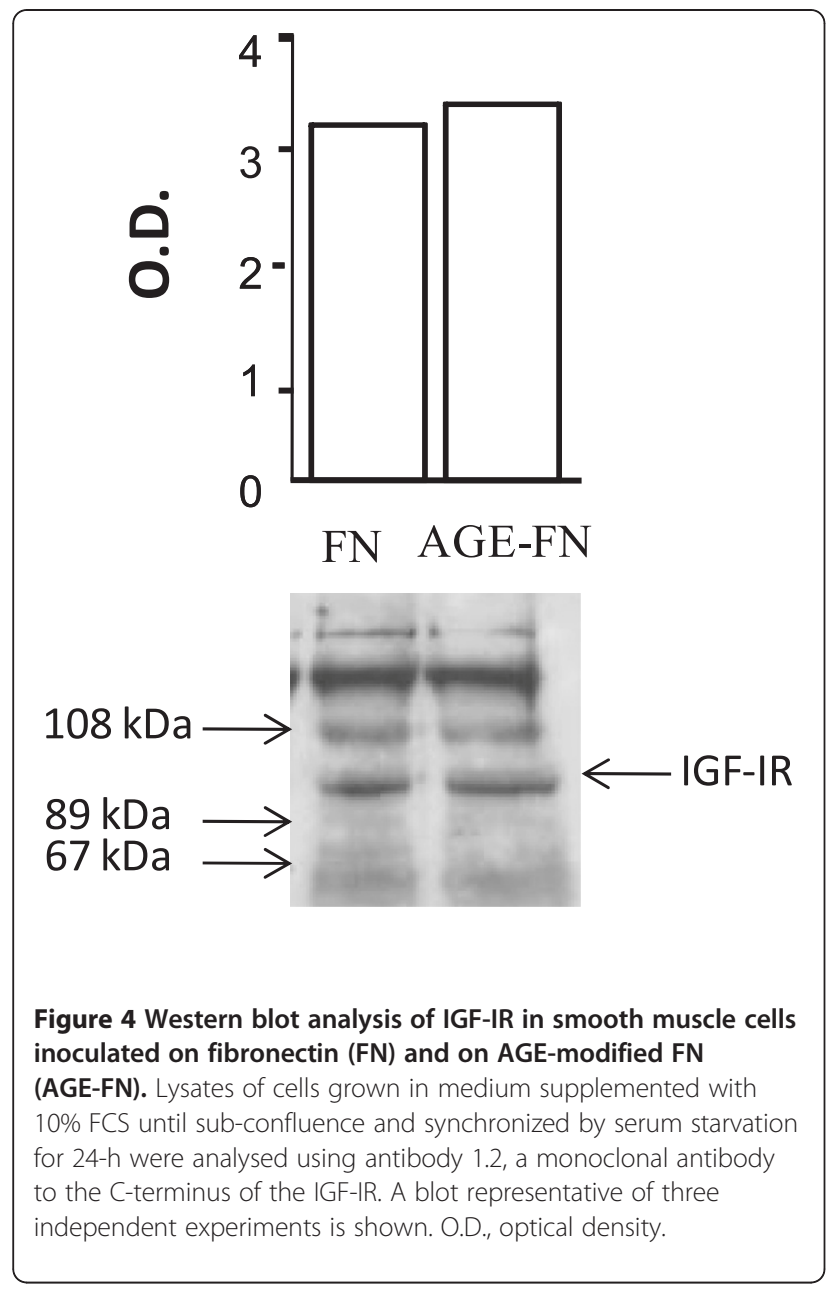

\section{IGF-IR and IGFBP-4 mRNA abundance}

We next examined the effect of AGE-FN on IGF-IR and IGFBP-4 expression before and after treatment with PDGF-BB, given the known influence of PDGF isoforms on the IGF-I axis in SMC [22,24]. IGF-I expression was not evaluated because preliminary experiments have demonstrated low expression levels of this growth factor in the studied cell line (data not shown). IGF-IR mRNA and IGFBP-4 mRNA abundances were not affected by AGE-FN in comparison to the abundance observed in cells grown on FN substrata after $24 \mathrm{~h}$, and treatment with PDGF-BB had no effect on the content of IGF-IR and IGFBP-4 mRNAs in relation to untreated cells in both substrata $(P>0.05)$ (Figure 7$)$, suggesting that the modulation of IGBBP-4 secretion observed after PDGF-BB treatment is probably due to post-transcriptional events.

\section{Discussion}

There is now a considerable body of evidence supporting an important role for AGEs and its receptors in the diabetic vascular dysfunction [38], such as the suppression of accelerated atherosclerotic lesion development by
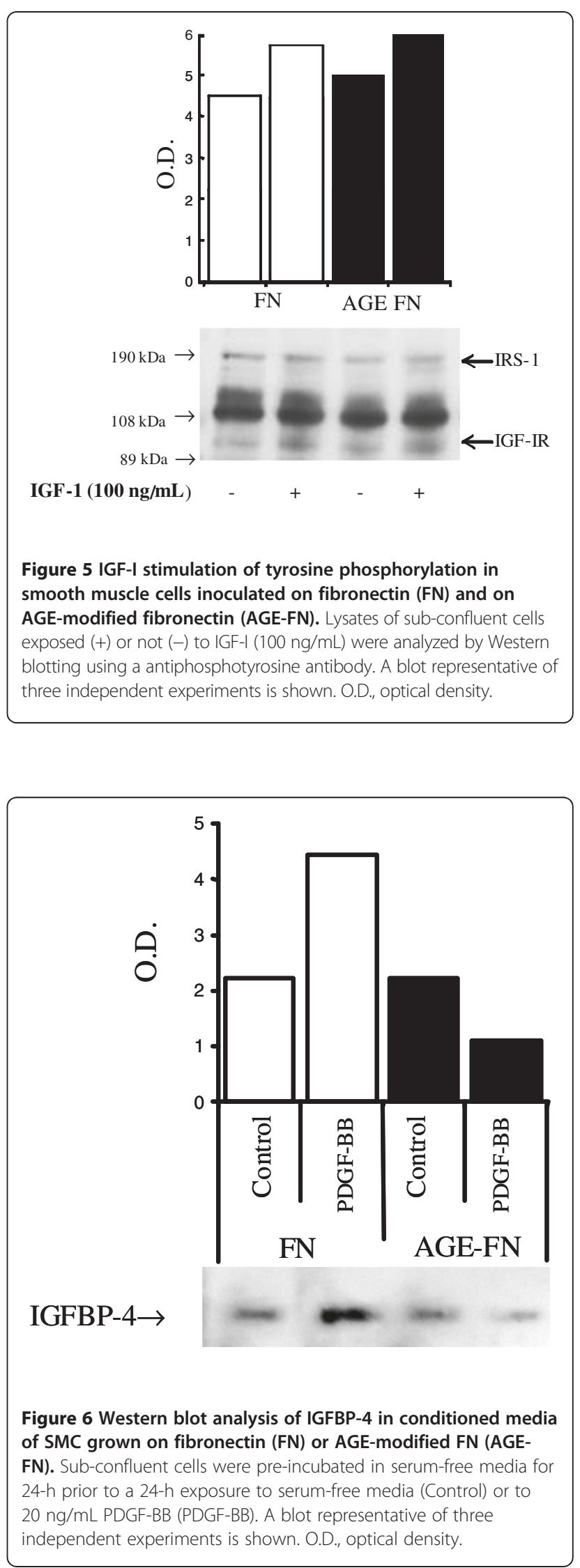


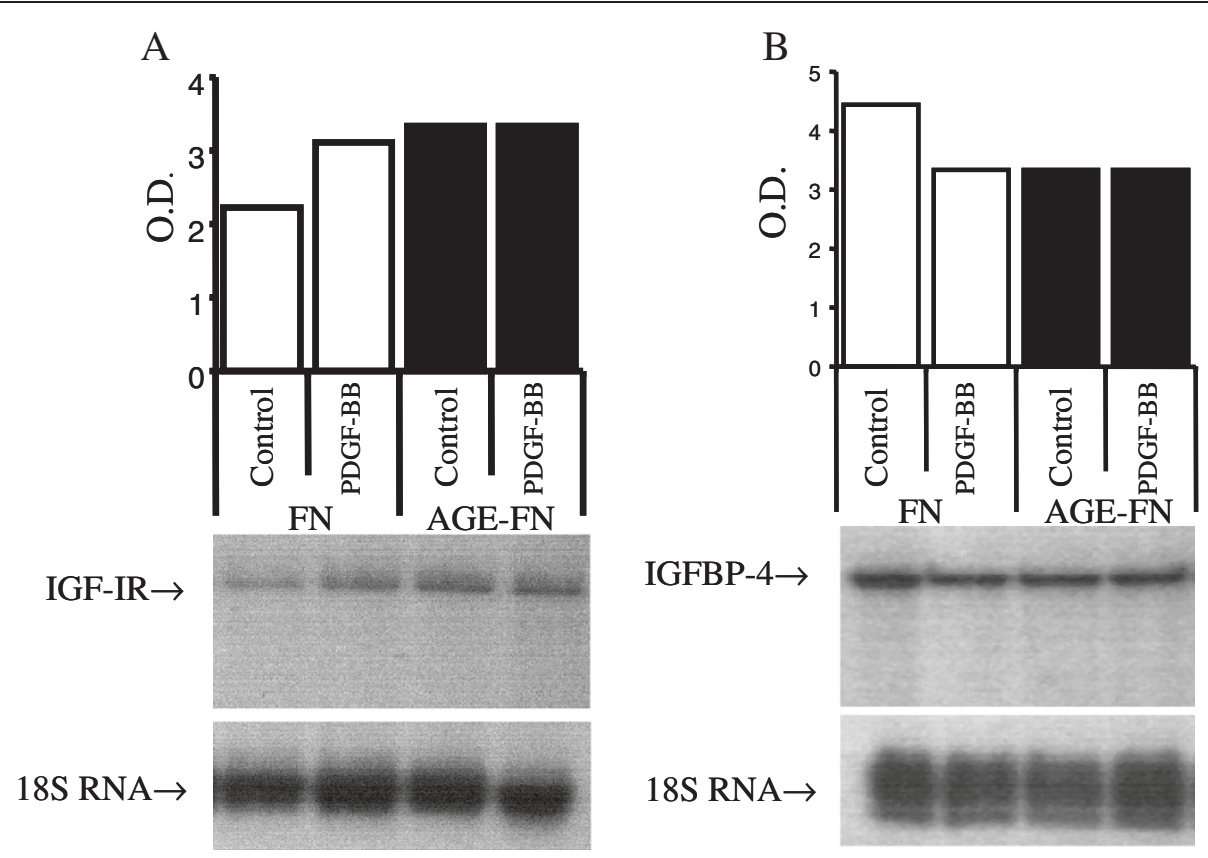

Figure 7 RNase protection assay analysis of IGF-IR (Panel A) and IGFBP-4 (Panel B) mRNA of SMC grown on fibronectin (FN) or AGEmodified FN (AGE-FN). Sub-confluent cells were pre-incubated in serum-free media for 24-h prior to a 24-h exposure to serum-free media (Control) or to $20 \mathrm{ng} / \mathrm{mL}$ PDGF-BB (PDGF-BB). Twenty micrograms of total RNA were cohybridized with hIGF-IR or hIGFBP-4 and 18S RNA riboprobes. A blot representative of three independent experiments is shown. O.D., optical density.

interruption of AGE-RAGE interaction in diabetic rodents [39]. Our finding of increased IGF-I induced human aortic SMC proliferation in presence of AGE-FN suggests a participation of this growth factor in the atherogenic process related to protein glycation. Given the findings of Chisalita et al. [40], who reported that the expression of IGF-IR is five-fold higher compared to the expression of insulin receptor in human aortic SMC, it is probable that the proliferative effect of IGF-I is being exerted through IGF-IR, although we had not found increased phosphorylation of IGF-IR.

Previous studies have already demonstrated a stimulatory effect of AGE on the growth of rat [41], rabbit [42], porcine [43] and human [44] vascular SMC. Seki et al. [45], who also reported a proliferative effect of AGE on rat SMC, did not detect any change in the phosphorylation of PDGF receptor. In common with the present study, SMC were chronically maintained in AGE and were acutely stimulated with the growth factor in the phosphorylation experiment. Thus, these two studies suggest that chronic exposure of SMC to AGE did not modify the phosphorylation status of PDGF and IGF receptors, although it positively affected cell proliferation. On the other hand, activation of $\mathrm{p} 42$ mitogen-activated protein kinase (MAPK) [42] and of p21 ${ }^{\text {ras }}$ MAP kinase pathway [46] were described in SMC acutely exposed to AGE, demonstrating the direct activation of these transduction pathways by AGE-RAGE interactions.

Human vascular SMCs synthesize and secrete IGFBP-2, $-4,-5$ and -6 . Their expression is regulated by many factors, including PDGF, and they are important determinants of SMC responses to IGF-I [47] inhibiting (IGFBP4) or potentiating (IGFBP-5) its mitogenic effect [48]. We evaluated IGFBP-4, the most abundant binding protein secreted by human SMC and found that AGE-FN modifies its modulation by PDGF-BB, decreasing IGFBP-4 production in comparison to FN substratum, in which PDGF-BB elicits an increased secretion. Since IGFBP-4 is known to inhibit IGF-I action, the reduction of IGFBP-4 secretion induced by PDGF-BB could result in augmented availability of IGF-I. It is well known that the functions of IGFBPs on vascular SMC are regulated by post-translational processing such as proteolysis [47]. In the case of IGFBP-4, the metalloproteinase pregnancy-associated plasma protein A (PAPP-A), expressed in vascular SMC [49], is recognized as the main protease. It remains to be elucidated if, in the presence of AGE-FN, PDGF-BB could induce PAPP-A expression, increasing IGFBP-4 proteolysis and eventually decreasing the abundance of this binding protein. This is an interesting possibility in light of previous works demonstrating that PAPP-A expression is stimulated by TNF- $\alpha$ in human coronary SMC [50] and in human fibroblasts [51] and that, in the latter cell type, 
$\mathrm{NF \kappa B}$ was identified as the primary mediator of TNF- $\alpha$ stimulated PAPP-A gene expression [52]. Both TNF- $\alpha$ [10] and NFKB $[13,45]$ are stimulated after cellular exposure to AGE-modified proteins.

Since we did not perform experiments evaluating autophosphorylation of PDGF-BB receptor, we cannot rule out that a decrease in PDGF-BB receptor signaling is taking place in presence of AGE-FN, which could partially explain an absence of PDGF-BB effect increasing IGFBP-4 in the conditioned media. A previous study of Cantero et al. found that dicarbonyl compounds, highly reactive compounds that react with proteins to form AGEs, modified PDGF-induced PDGFR $\beta$-phosphorylation by inhibiting its intrinsic tyrosine kinase activity [53].

\section{Conclusions}

This study suggests that AGE-modified FN modulates SMC's response to IGF-I and PDGF-BB, both present in the vascular wall, potentially contributing to the pathogenesis of diabetes associated atherosclerosis by increasing SMC susceptibility to IGF-I mitogenic effects.

\section{Abbreviations \\ AGE: Advanced glycation end products; AGE-FN: Advanced glycation end product-modified fibronectin; IGF: Insulin-like growth factor; IGFBP: Insulin- like growth factor binding protein; FN: Fibronectin; PAPP-A: Pregnancy- associated plasma protein A; PDGF: Platelet-derived growth factor; SMC: Smooth muscle cells.}

\section{Competing interests}

The authors declare that there is no competing interests that would prejudice the impartiality of this scientific work.

\section{Authors' contributions}

MLCG performed the experiments and prepared the manuscript, MRAZ contributed to experiments, DLR provided reagents and advice and reviewed the paper, DGN designed the study, obtained funding, analyzed the data and reviewed the paper. All authors read and approved the final manuscript.

\section{Acknowledgements}

This study was supported by FAPESP (Process number 91/3617-8), São Paulo, Brazil. We are grateful to Dr. James K. McDougall (Fred Hutchinson Cancer Research Center. Seatle) for providing the human immortalized aortic SMC line.

\section{Author details}

${ }^{1}$ Laboratory for Cellular and Molecular Endocrinology (LIM-25). Hospital das Clínicas da Faculdade de Medicina da Universidade de São Paulo, Av. Dr. Arnaldo, 455, Sala 4305, São Paulo, Brazil. 'niversidade Santo Amaro (UNISA), R. Enéas de Siqueira Neto, 340, São Paulo, Brazil. ${ }^{3}$ Division of Endocrinology and Diabetes, Department of Medicine, The Mount Sinai School of Medicine, 1 Gustave Levy PlaceBox 1055New York, USA. ${ }^{4}$ Laboratory for Clinical and Experimental Gastroenterology (LIM-07). Hospital das Clínicas da Faculdade de Medicina da Universidade de São Paulo, Av. Dr. Arnaldo, 455, Sala \#4387, São Paulo, Brazil.

Received: 21 June 2011 Accepted: 9 April 2012

Published: 3 May 2012

\section{References}

1. Schwartz CJ, Valente AJ, Sprague EA, Kelley JL, Cayatte AJ, Rozek MM: Pathogenesis of the atherosclerotic lesion. Implications for diabetes mellitus. Diabetes Care 1992, 15:1156-1167.
2. StamLer J, Vaccaro O, Neaton JD, Wentworth D: Diabetes, other risk factors, and 12-yr cardiovascular mortality for men screened in the Multiple Risk Factor Intervention Trial. Diabetes Care 1993, 16:434-444.

3. Brownlee M, Cerami A, Vlassara H: Advanced glycosylation end products in tissue and the biochemical basis of diabetic complications. N Engl J Med 1988, 318:1315-1321.

4. King GL, Kunisaki M, Nishio $Y$, Inoguchi T, Shiba T, Xia P: Biochemical and molecular mechanisms in the development of diabetic vascular complications. Diabetes 1996, 45(Suppl 3):105-108.

5. Vlassara $\mathrm{H}$ : Recent progress on the biologic and clinical significance of advanced glycosylation end products. J Lab Clin Med 1994, 124:19-30.

6. Tsilbary EC, Charonis AS, Reger LA, Wohlhueter RM, Furcht LT: The effect of nonenzymatic glycosylation on the binding of the main noncollagenous NC1 domain to type IV collagen. J Biol Chem 1988, 263:4302-4308.

7. Brownlee M: Glycation and diabetic complications. Diabetes 1994, 43:836-841.

8. Charonis AS, Reger LA, Dege JE, Kouzi-Koliakos K, Furcht LT, Wohlhueter RM, Tsilbary EC: Laminin alterations after in vitro nonenzymatic glycosylation. Diabetes 1990, 39:807-814.

9. Cohen MP, Ku L: Inhibition of fibronectin binding to matrix components by nonenzymatic glycosylation. Diabetes 1984, 33:970-974.

10. Vlassara H, Brownlee M, Manogue KR, Dinarello C, Pasagian A: Cachectin/ TNF and IL-1 induced by glucose modified proteins: role in normal tissue remodeling. Science 1988, 240:1546-1548.

11. Kirstein M, Brett J, Radoff S, Ogawa S, Stern D, Vlassara H: Advanced protein glycosylation induces transendothelial human monocyte chemotaxis and secretion of PDGF: role in vascular disease of diabetes and aging. Proc Natl Acad Sci USA 1990, 87:9010-9014.

12. Kirstein M, Aston C, Hintz R, Vlassara H: Receptor-specific induction of insulin-like growth factor I (IGF-I) in human monocytes by advanced glycosylation endproduct-modified proteins. J Clin Invest 1992, 90:439-446.

13. Kislinger T, Fu C, Huber B, Qu W, Taguchi A, Yan SD, Hofmann M, Yan SF, Pischetsrieder M, Stern D, Schmidt AM: N-(Carboxymethyl) Lysine adducts of proteins are ligands for receptor for advanced glycation end products that activate cell signaling pathways and modulate gene expression. J Biol Chem 1999, 274:31740-31749.

14. Ross R: The pathogenesis of atherosclerosis: a perspective for the 1990s. Nature 1993, 362:801-809.

15. Stenman S, Von Smitten K, Vaheri A: Fibronectin and atherosclerosis. Acta Med Scand Supp/ 1980, 642:165-170.

16. Orekhov AN, Andreeva ER, Shekhonin BV, Tertov W, Smirnov VN: Content and localization of fibronectin in normal intima, atherosclerotic plaque, and underlying media of human aorta. Arteriosclerosis 1984, 53:213-219.

17. Thyberg J, Hedin U, Sjölund M, Palmberg L, Bottger BA: Regulation of differentiated properties and proliferation of arterial smooth muscle cells. Arteriosclerosis 1990, 10:966-990.

18. Stiles CD, Capone Gl, Sher CD, Antoniades HN, Van Wyk JJ, Pledger WJ: Dual control of cell growth by somatomedin and platelet-derived growth factor. Proc Natl Acad Sci USA 1979, 76:1279-1283.

19. Clemmons DR: Exposure to platelet-derived growth factor modulates the porcine aortic smooth muscle cell response to somatomedin-C. Endocrinology 1985, 117:77-83.

20. Bornfeldt KE, Arnqvist HJ, Norstedt G: Regulation of insulin-like growth factor-I gene expression by growth factors in cultured vascular smooth muscle cells. J Endocrinol 1990, 125:381-386.

21. Delafontaine P, Lou H, Alexander RW: Regulation of insulin-like growth factor I messenger RNA levels in vascular smooth muscle cells. Hypertension 1991, 18:742-747.

22. Giannella-Neto D, Kamyar A, Sharifi B, Pirola CJ, Kupfer J, Rosenfeld RG, Forrester JS, Fagin JA: Platelet-derived growth factor isoforms decrease insulin-like growth factor I gene expression in rat vascular smooth muscle cells and selectively stimulate the biosynthesis of insulin-like growth factor binding protein 4. Circ Res 1992, 71:646-656.

23. Clemmons DR: The role of insulin-like growth factor binding proteins in controlling the expression of IGF actions. In Molecular and cellular biology of insulin-like growth factor and their receptors. Edited by Le Roith D, Razada MK. Gainesville, FL: Plenum Press; 1989:381-394.

24. Cohick WS, Gockerman A, Clemmons DR: Regulation of insulin-like growth factor (IGF) binding protein-2 synthesis and degradation by platelet-derived growth factor and the IGFs is enhanced by serum deprivation in vascular smooth muscle cells. J Cell Physiol 1995, 164:187-196. 
25. Cohick WS, Gockerman A, Clemmons DR: Vascular smooth muscle cells synthesize two forms of insulin-like growth factor binding proteins which are regulated differently by the insulin-like growth factors. J Cell Physiol 1993, 157:52-60.

26. Pongor S, Ulrich PC, Benesath A, Cerami A: Aging of proteins: isolation and identification of a fluorescent chromophore from the reaction of polypeptides with glucose. Proc Natl Acad Sci USA 1984, 81:2684-2688.

27. Vissers MC, Winterbourn CC: Oxidative damage to fibronectin. II. The effect of H2O2 and the hydroxyl radical. Arch Biochem Biophys 1991, 285:357-364.

28. LaemmLi U: Cleavage of the structural proteins during the assembly of the bacteriophage T4. Nature 1970, 227:680-685.

29. Perez-Reyes N, Halbert CL, Smith PP, Benditt EP, McDougall JK: Immortalization of primary human smooth muscle cells. Proc Natl Acad Sci USA 1992, 89:1224-1228.

30. Kato H, Faria TN, Stannard B, Roberts CT Jr, LeRoith D: Role of tyrosine kinase activity in signal transduction by the insulin-like growth factor-I (IGF-I) receptor. Characterization of kinase-deficient IGF-I receptors and the action of an IGF-I-mimetic antibody (alpha IR-3). J Biol Chem 1993, 268:2655-2661.

31. Munson PJ, Rodbard D: LIGAND: A versatile computerized approach for characterization of ligand-binding systems. Anal Biochem 1980, 107:220-239.

32. Stannard B, Blakesley V, Kato H, Roberts CT Jr, LeRoith D: Single tyrosine substitution in the insulin-Like growth factor I receptor inhibits ligandinduced receptor autophosphorylation and internalization, but not mitogenesis. Endocrinology 1995, 136:4918-4924

33. Bradford MM: A rapid and sensitive method for quantitation of microgram quantities of protein utilizing the principle of protein dye binding. Anal Biochem 1976, 72:248-254.

34. Lowe WL Jr, Roberts CT Jr, Lasky SR, LeRoith D: Differential expression of alternative 5 ' untranslated regions in mRNAs encoding rat insulin-like growth factor I. Proc Natl Acad Sci U S A 1987, 84:8946-8950.

35. de Lacerda L, Carvalho JA, Stannard B, Werner H, Boguszewski MC, Sandrini R, Malozowski SN, LeRoith D, Underwood LE: In vitro and in vivo responses to short-term recombinant human insulin-like growth factor-1 (IGF-I) in a severely growth-retarded girl with ring chromosome 15 and deletion of a single allele for the type 1 IGF receptor gene. Clin Endocrinol 1999, 51:541550

36. Shimasaki S, Uchiyama F, Shimonaka M, Ling N: Molecular cloning of the cDNAs encoding a novel insulin-like growth factor binding protein from rat and human. Mol Endocrinol 1990, 4:1451-1458.

37. Bang P, Eriksson U, Sara V, Wivall I, Hall K: Comparison of acid ethanol extraction and acid gel filtration prior to IGF-I and IGF-II radioimmunoassays: improvement of determinations in acid ethanol extracts by the use of truncated IGF-I as radioligand. Acta Endocrinologica (Copenh) 1991, 124:620-629.

38. Schalkwijk CG, Miyata T. Early- and advanced non-enzymatic glycation in diabetic vascular complications: the search for therapeutics. Amino Acids 2010, Oct 20 [Epub ahead of print].

39. Park L, Raman KG, Lee KJ, Yan L, Ferran L, Chow WS, Stern D, Schmidt AM: Suppression of accelerated diabetic atherosclerosis by the soluble receptor for advanced glycation endproducts. Nat Med 1998, 4:10251031.

40. Chisalita SI, Johansson GS, Liefvendahl E, Bäck K, Arnqvist HJ: Human aortic smooth muscle cells are insulin resistant at the receptor level but sensitive to IGF1 and IGF2. J Mol Endocrinol 2009, 43:231-239.

41. Wang R, Kudo M, Yokoyama M, Asano G: Roles of advanced glycation endproducts (AGE) and receptor for AGE on vascular smooth muscle cell growth. J Nippon Med Sch 2001, 68:472-481.

42. Satoh H, Togo M, Hara M, Miyata T, Han K, Maekawa H, Ohno M, Hashimoto Y, Kurokawa K, Watanabe T: Advanced glycation endproducts stimulate Mitogen- Activated Protein Kinase and proliferation in rabbit vascular smooth muscle cells. Biochem Biophys Res Commun 1997, 239:111-115.

43. David KC, Scott RH, Nixon GF: Advanced glycation endproducts induce a proliferative response in vascular smooth muscle cells via altered calcium signaling. Biochem Pharmacol 2008, 76:1110-1120.

44. Cai Q, Li BY, Gao HQ, Zhang JH, Wang JF, Yu F, Yin M, Zhang Z: Grape seed procyanidin b2 inhibits human aortic smooth muscle cell proliferation and migration induced by advanced glycation end products. Biosci Biotechnol Biochem 2011, 75:1692-1697.

45. Seki N, Hashimoto N, Sano H, Horiuchi S, Yagui K, Makino H, Saito Y: Mechanisms Involved in the Stimulatory Effect of Advanced Glycation
End Products on Growth of Rat Aortic Smooth Muscle Cells. Metabolism 2003, 52:1558-1563.

46. Lande HM, Tauras JM, Ogiste JS, Hori O, Moss RA, Schmidt AM: Activation of the receptor for advanced glycation end products triggers a p21 (ras)- dependent mitogen-activated protein kinase pathway regulated by oxidant stress. J Biol Chem 1997, 272:17810-17814.

47. Delafontaine P, Song Y-H, Li Y: Expression, Regulation, and Function of IGF-1, IGF-1R, and IGF-1 Binding Proteins in Blood Vessels. Arterioscler Thromb Vasc Biol 2004, 24:435-444.

48. Duan C, Clemmons DR: Differential expression and biological effects of insulin-like growth factor-binding protein- 4 and -5 in vascular smooth muscle cells. J Biol Chem 1998, 273:16836-16842.

49. Bayes-Genis A, Schwartz RS, Lewis DA, Overgaard MT, Christiansen M, Oxvig C, Ashai K, Holmes DR Jr, Conover CA: Insulin-like growth factor binding protein-4 protease produced by smooth muscle cells increases in the coronary artery after angioplasty. Arterioscler Thromb Vasc Biol 1999, 21:335-341

50. Conover CA, Bale LK, Harrington SC, Resch ZT, Overgaard MT, Oxvig C: Cytokine stimulation of pregnancy-associated plasma protein $\mathrm{A}$ expression in human coronary artery smooth muscle cells: inhibition by resveratrol. Am J Physiol 2006, 290:C183-C188.

51. Resch ZT, Chen B-K, Bale LK, Oxvig C, Overgaard MT, Conover CA: Pregnancy-associated plasma protein A gene expression as a target of inflammatory cytokines. Endocrinology 2004, 145:1124-1129.

52. Resch ZT, Oxvig C, Bale LK, Conover CA: Stress-activated signaling pathways mediate the stimulation of pregnancy-associated plasma protein-A expression in cultured human fibroblasts. Endocrinology 2006, 147:885-890.

53. Cantero AV, Portero-Otín M, Ayala V, Auge N, Sanson M, Elbaz M, Thiers JC, Pamplona R, Salvayre R, Nègre- Salvayre A: Methylglyoxal induces advanced glycation end product (AGEs) formation and dysfunction of PDGF receptor-beta: implications for diabetic atherosclerosis. FASEB J 2007, 21:3096-3106.

doi:10.1186/1758-5996-4-19

Cite this article as: Corrêa-Giannella et al:: Fibronectin glycation increases IGF-I induced proliferation of human aortic smooth muscle cells. Diabetology \& Metabolic Syndrome 2012 4:19.

\section{Submit your next manuscript to BioMed Central and take full advantage of:}

- Convenient online submission

- Thorough peer review

- No space constraints or color figure charges

- Immediate publication on acceptance

- Inclusion in PubMed, CAS, Scopus and Google Scholar

- Research which is freely available for redistribution
C) Biomed Central 